\title{
PENGETAHUAN GIZI SISWA YANG MENGIKUTI EKSTRAKURIKULER SEKOLAH MENENGAH PERTAMA NEGERI 4 PADANG
}

\author{
Muhammad Arnado ${ }^{1}$, Kamal Firdaus ${ }^{2}$, Kibadra $^{2}$ \\ ${ }^{1}$ Program Studi Pendidikan Jasmani Kesehatan dan Rekreasi, Fakultas Ilmu Keolahragaan, \\ Universitas Negeri Padang, Jalan Prof. DR. Hamka Air Tawar Barat, Padang, 25132, Indonesia \\ ${ }^{2}$ Program Studi Pendidikan Jasmani Kesehatan dan Rekreasi, Fakultas Ilmu Keolahragaan, \\ Universitas Negeri Padang, Jalan Prof. DR. Hamka Air Tawar Barat, Padang, 25132, Indonesia \\ E-mail: arnando@fik.unp.ac.id ${ }^{1}, \underline{\text { kamalfirdaus@ fik.unp.ac.id }}{ }^{2}, \underline{\text { kibadra@ fik.unp.ac.id }}$
}

\begin{abstract}
Abstrak
Penelitian ini bertujuan untuk mengetahui tingkat pengetahui gizi siswa yang mengikuti ekstrakurikuler (olahraga) SMP N 4 Padang. Jenis penelitian ini adalah deskripsi dan data langsung diambil melalui angket penelitian. Populasi adalah siswa SMP N 4 Padang yang mengikuti kegiatan ekstrakuriuler (Olahraga). Penarikan sampel penelitian menggunakan teknik purposive samples. Jumlah sampel 63 orang. Data yang dikumpulkan melalui angket dianalisis dengan statistik deskriptif formula persentase secara manual. Sehingga di dapat hasil penelitian yang menunjukkan bahwa siswa yang memiliki pengetahuan baik $(26,9 \%)$, pengetahuan sedang $(55,6 \%)$ dan yang memiliki pengetahuan kurang (17,5\%). Berdasarkan analisis data dapat disimpulkan bahwa, gambaran pengetahuan gizi siswa yang mengikuti eksetrakurikuler (olahraga) di SMP N 4 Padang termasuk dalam klasifikasi sedang.
\end{abstract}

Kata Kunci: Gizi, Ekstrakurikuler

\section{PENDAHULUAN}

Pengetahuan gizi masyarakat dapat digunakan sebagai ukuran keberhasilan pembangunan (Pergizi Pangan indonesia, 1990:96). Oleh karena itu, di Negara-negara berkembang masalah gizi adalah masalah yang perlu ditanggulangi dengan segera sebab masalah yang perlu ditanggulangi dengan segera sebab masalah tersebut sangat erat hubungannya dengan kemajuan suatu bangsa dan negara.

Anak yang mempunyai status gizi yang baik makan pertumbuhannya dan perkembangannya akan berjalan dengan seimbang dan sehat. Bila seseorang telah sehat tentu akan dapat melaksanakan tugasnya seharihari dengan baik. Ditambah status gizi yang baik merupakan salah satu syarat penting dalam mencapai kesehatan yang optimal, tidak saja ditandai dengan penampilan yang baik secara fisik, tetapi juga mental dan emosi.

Selanjutnya jika status gizi anak rendah, anak tidak dapat bergerak dengan baik dan kosekuensinya kemampuan motoriknya juga rendah. Sajogyo dalam Gusril (2004:131) menegaskan bahwa "gizi yang kurang atau buruk pada anak-anak dapat berakibat terganggunya pertumbuhan jasmani dan kecerdasannya".
Adapun tanda-tanda anak yang gizinya kurang yaitu: Badan kurus, pertumbuhannya terhambat, hal ini terjadi karena kurang zat sumber tenaga dan kurang protein (zat pembangun), kurang gairah dan kurang lincah dan akan tertinggal dalam belajar, kurang gesit dalam bergaul sesama anak atau kurang tanggap atas lingkungannya.

Selain itu dampak status gizi anak yang berlebih (over weight) juga menimbulkan masalah berat badan yang berlebih. Hal ini tentu akan mengganggu kemampuan motoriknya karena dalam melakukan gerak tidak dapat keseimbangan antara tubuh dengan pusat gravitasi dan juga memerlukan energi yang banyak.

Adapun fungsi makanan bagi tubuh anak menurut Djaeni (2004:20) yaitu: (1) Sebagai sumber energi; (2) Menyokong pertumbuhan badan; (3) Memellihara jaringan tubuh, mengganti yang rusak atau aus dipakai; (4) Mengatur metabolisme dan mengatur keseimbangan; (5) Berperan di dalam mekanisme pertahanan tubuh terhadap berbagai penyakit". Dan salah satu upaya pemerintah Indonesia dalam masalah gizi seimbang adalah membuat

Program Pedoman Umum Gizi Seimbang (PUGS) yang terdiri dari 13 item, yaitu "(a) 
Makanlah makanan yang beranekaragam setiap hari; (b) Makalah makanan yang cukup energi; (c) Untuk sumber energi, upayakan agar separuhnya berasal dari makanan yang mengandung zat karbohidra kompleks; (d) Upayakan agar sumber energi dati minyak dan lemak tidak lebih dari seperempat dari energi total yang anda butuhkan; (e) Makanlah banyak mangkanan yang kaya akan zat besi; (f) Berikan air susu ibu untuk bayi usia 4 tahun; (g) Biasakan makan pagi setiap hari; (h) Minun air bersih dan sehat dalam jumlah yang cukup; (i) Berolahraga dengan teratur untuk menjaga kebugaran badan; (j) Hindarilah minuman berakohol; (k) Makanlah makan yang dimasak/atau di hidangkan dengan bersih dan tidak tercemar; (1) Bacalah selalu tabel pada kemasan makanan".

Dari pernyataan di atas dapat kita simpulkan bahwa gizi yang ditidak seimbang serta derajat kesehatan siswa yang rendah akan menghambat pertumbuhan otak dalam mencatat, menyerap, menyimpan, memproduksi, dan merekonstruksi informasi. Disamping itu, rendahnya derajat kesehatan dan gizi anak akan menghambat pertumbuhan fisik dan motorik anak, agar tercapainya status gizi anak yang optimal diperlukan berbagai upaya perbaikan gizi, salah satunya adalah dengan memberikan pengetahuan tentang gizi ke pada siswa.

Sehubungan dengan itu SMP N 4 Padang sebagai slah satu lembaga pendidikan di Sumatera Barat telah memberikan pengetahuan tentang gizi yang diberikan melalui bidang studi Ilmu Pengetahuan Alam (IPA), Olahraga (ORKES), serta Program Usaha Kesehatan Sekolah (UKS) yang bertujuan memberikan pengetahuan tentang gizi, sekaligus terjadinya perubahan sikap dan tingkah laku sehingga menjadi pola hidup siswa sehari-hari.

Selain pengetahuan gizi yang diberikan melalui bidang studi di atas SMP Negeri 4 Padang juga memberikan pengetahuan umum yang diberikan melalui bidan studi yang lain, seperti pada bidang studi Bahasa Indonesia, matematik dan lain-lain. Dan menyalurkan minat dan bakat siswa maka SMP Negeri 4 Padang juga mengadakan kegiatan ekstrakurikuler. Seperti kita ketahui bahwa siswa SMP merupakan kelompok usia yang sedang aktif melakukan berbagai kegiatan, baik kegiatan intrakurikuler maupun ekstrakurikuler.

Siswa yang mengikuti kegiatan ekstrakurikuler ini tentu membutuhkan energi dan zat gizi yang banyak berkisar 2400 kalori, jumlah energi dan zat gizi yang banyak tentu didapat dari adanya asupan gizi yang cukup. Namun belum banyak siswa yang mengetahui tentang hal tersebut.

Akhirnya siswa setelah sampai disekolah membeli makanan atau jajanan yang kurang bergizi dan kurang sehat. Hal ini tampak pada kondisi fisiknya yang kurang seimbang, selain dari itu terlihat dari postur tubuh siswa dimana tidak ada keseimbangan antara berat badan dan tinggi badan sementara postur tubuhnya pun kecil atau kurus dan sebaliknya mempunyai berat badan berlebih (obesitas).

Hal ini tentu mempengaruhi kemampuan fisik siswa, sehingga banyak siswa yang terlihat loyo, malas dan mengantuk pada saat mengikuti jam pembelajaran. Prilaku yang kurang sehat itu kemungkinan disebabkan oleh rendahnya pengetahuan siswa tentang gizi dan makanan sehat, latar belakang pendidikan orang tuanya rendah, perekonomian orang tua yang kurang, kurangnya informasi dari media, banyaknya warung yang menjual makanan yang kurang sehat, dan minimnya pemberian pengetahuan gizi kepada siswa yang diberikan melalui program studi Ilmu Pengetahuan Alam (IPA), Olahraga (ORKES), dan Usaha Kesehatan Sekolah (UKS).

\section{METODE PENELITIAN}

Jenis penelitian ini adalah deskriptif bertujuan mengungkapkan keadaan data sebagaimana mestinya. Sudjana (1984:64) mengungkapkan bahwa "penelitian deskriptif adalah penelitian yang berusaha mendeskriptifkan suatu gejala dan kejadian yang terjadi di masa sekarang dengan kata lain peneltian pada masalah-masalah aktual sebgaiman adanya saat penelitian dilakukan". Pupulasi dalam penelitian ini adalah siswa SMP N 4 Padang yang mengikuti ekstrakurikuler (Olahraga). Sehingga sampel pada penelitian ini berjumlah 63 orang siswa.

Tes pengetahuan gizi menggunakan angket (kuesioner). Sugiono (2006:158) mengemukakan "kuesioner merupakan teknik pengumpulan data yang dengan cara memberikan seperangkat pertanyaan atau pernyataan tertulis kepada responden untuk dijawabnya". Prosedur penelitian sebelum angket digunakan terlebih dahulu angket dilakukan uji coba untuk melihat sahih (validitas) dan keterandalan (realibilitas) angket penelitian. Setelah dilakukan uji coba dari 42 soal maka didapatlah soal yang dinyatakan valid dan reliabel berjumlah 35 soal.

\section{HASIL}


Hasil analisis penelitian pengetahuan gizi siswa yang mengikuti ekstrakurikuler (olahraga) SMP N 4 Padang dapat dilihat pada tabel dibawah ini.

Tabel 1.

Pengethuan gizi siswa yang mengikuti ekstrakurikuler (olahraga) SMP N 4 Padang

\begin{tabular}{|c|c|c|c|}
\hline $\begin{array}{c}\text { Skor } \\
\text { Pengetahuan } \\
\text { Gizi (\%) }\end{array}$ & Kriteria & $\mathbf{n}$ & $\mathbf{\%}$ \\
\hline$>80$ & Baik & 17 & 26,9 \\
$67-80$ & Sedang & 35 & 55,6 \\
$<67$ & Kurang & 11 & 17,5 \\
\hline Jumlah & & $\mathbf{6 3}$ & $\mathbf{1 0 0}$ \\
\hline
\end{tabular}

Untuk menentukan kriteria tingkat pengetahuan gizi siswa peneliti menggunakan tiga pengelompokan yang didapat melalui ratarata (mean) dan standar deviasi (sd). Selanjutnya di analisi dengan menggunakan teknik analisis data statistik deskriptif yang menggunakn frekuensi (Usman, 1995:74). Sehingga didapatlah siswa yang memiliki pengetahuan gizi kurang dengan skor $<67$ hanya 11 orang $(17,5$ $\%)$, pengetahuan gizi sedang skor $67-80$ sebanyak 35 orang $(55,6 \%)$ dan yang memiliki pengetahuan baik skor $>80$ adalah 17 orang $(26,9 \%)$.

Berdasarkan uraian tersebut dapat disimpulkan dari 63 orang sampel hanya 17 orang $(26,9 \%)$ yang mempunyai pengetahuan baik, 35 orang $(55,6 \%)$ mempunyai pengetahuan gizi sedang dan 11 orang $(17,5 \%)$ mempunyai pengetahuan gizi kurang. Oleh karena itu dapat disimpulkan bahwa pengetahuan gizi siswa yang mengikuti ekstrakulikuler (olahraga) SMP N 4 Padang dapat dikategorikan sedang. Untuk lebih jelasnya dapat dilihat pada grafik 1 .

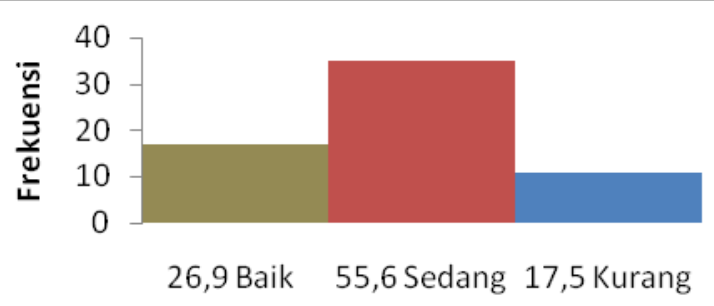

17

35

11

Kategori

Grafik 1.

\section{Pengetahuan gizi siswa yang mengikuti ekstrakurikuler (Olahraga)}

\section{PEMBAHASAN}

Dari tabel diketahui bahwa pengetahuan gizi siswa sebagian besar berada dalam kategori sedang $(55,6 \%)$. Hanya $26,9 \%$ skor pengetahuan gizi siswa yang tergolong baik dan masih ada skor pengetahuan gizi siswa tergolong rendah $(17,5 \%)$. Hal ini dimungkinkan tingkat penddidikan orang tua yang banyak setingkat SMA/sederajat dan jarangnya penyuluhanpenyuluhan gizi dilakukan di sekolah-sekolah melalui UKS dan kegiatan lainnya.

Menurut Notoadmodjo (2005), pengetahuan seseorang dipengaruhi oleh beberapa faktor diantaranya: "pendidikan, latar belakang pendidikan orang tua, paparan terhadap informasi, sosial budaya, motivasi, dan persepsi”. Sedangkan menurut Binyamin Bloom dalam Winkel (1996:143) menyatakan bahwa "pengetahuan adalah salah satu aspek yang termasuk dalam ranah kognitif dan dapat dijadikan bentuk pengukuran hasil penelitian atau hasil belajar siswa". Selanjutnya Muhibbin Syah (2003:144) menyatakan bahwa faktorfaktor yang mempengaruhi belajar siswa dapatdibedakan menjadi 3 (tiga) macam, yakni:

1. Faktor internal (faktor dari dalam siswa), yakni kondisi/keadaan jasmani siswa, seperti status gizi siswa, tingkat kesehatan alat indra dan dari rohani siswa, seperti tingkat kecerdasan, sikap, bakat, minat dan motivasi siswa.

2. Faktor ekternal (faktor dari luar siswa), yakni kondisi lingkungan yang berbentuk sosial seperti lingkungan sekolah, orang tua. Masyarakat dan kondisi lingkungan yang berbentuk non sosial, seperti gedung sekolah, sarana dan prasarana di sekolah dan keadaan rumah yang kurang baik.

3. Faktor pendekatan belajar (approach to learning), yakni jenis upaya belajar siswa yang meliputi strategi dan metode yang digunakan siswa untuk melakukan kegiatan mempelajari materi-materi pembelajaran.

Dalam penelitian ini diketahui bahwa pengetahuan siswa SMP N 4 Padang termasuk dalam kategori sedang, keadaan ini dapat diakibatkan oleh beberapa faktor, diantaranya disebabkan oleh latar belakang orang tua yang sedang, dimana diketahui bahwa sebagian besar pendidikan ibu adalah tamatan SMA/sederajat begitu juga dengan pendidikan ayah, juga ditemukan tamatan SMA/sederajat. Jadi cukup 
sedangnya tingkat pendidika orang tua berpengaruh sehingga menghasilkan pengetahuan gizi siswa sebagian besar berada dalam kategori sedang.

Orang tua yang mempunyai pendidikan cukup baik secara otomatis akan berusaha mengajarkan pada anaknya tentang sesuatu yang seiranya mutlak diketahui oleh anak, salah satunya ialah pengetahuan gizi. Dan tidak menutup kemungkinan bahwa pengetahuan orang tentang materi gizi juga memiliki kelemahan ataupun kekurangan sesuai dengan tingkat pendidikannya.

Selain itu, pngetahuan gizi yang diberikan melalui bidang studi pendidikan juga mempunyai peranan penting, karena pemberian pengetahuan gizi yang diberikan harus sesuai dengan DepKes RI (1981:105) yang menyatakan bahwa pengetahuan gizi yang harus diberikan dan telah disusun sesuai dengan kebutuhan dan sarana dalam rangka usaha kesehatan sekolah (UKS), meliputi:

1. Kegunaan makanan bagi gizi

2. Pengertian tentang gizi

3. Makanan sehat atau pola menu seimbang yang telah dikenal dengan slogan empat sehat lima sempurna

4. Cara memilih dan mengelola makanan dengan baik

5. Jenis dan sumber zat gizi

6. Penyakit dan akibat kekurangan zat gizi dan cara penaggulannya

Namun di dalam pemberian pengetahuan melalui bidang pendidikan juga di dapat kelemahan atau kekurangan tertentu seperti metode yang digunakan guru, agar materi yang diberikan tidak membosankan, alat atau media yang digunakan para staf administrasi dan teman sekelas yang dapat berpengaruh terhadap proses belajar seorang siswa.

Dan untuk menambah pengetahuan siswa tentang gizi selain pengetahuan yang diberikan oleh orang tua dan sekolah, siswa juga dapat mengetahui infomasi yang diberikan melalui media massa dan elektronik. Sedang daari hasil penelitian tentang pengetahuan gizi sebagian besar siswa menyatakan hanya bersumber dari orang tua, teman, dan sekolah (93,7\%), sedangkan dari media massa dan elektonik hanya $(6,3 \%)$.

Padahal pengaruh dari media massa dan eletronik juga mempunyai faktor informasi yang berpengaruh terhadap pengetahuan siswa seperti informasi yang diberikan melalui televisi, majalah-majalah, buku, koran mauupun internet, itu juga mempunyai peranan penting di dalam mendapatkan informasi-informasi pengetahuan tentang gizi.

Informasi tersebut tidak akan bisa di dapat jika minat, keinginan, dan motivasi siswa terhadap pengetahuan kesehatan yang diberikan melalui media massa ataupun elektronik tidak pernah dilihat, didengar, maupun dibaca. Sepeti yang kita tahu siswa ataupun golongan usia remaja sangat menyukai program yang diberikan melalui televisi maupun internet, tetapi program yang sangat digemari oleh kalangan remaja berupa film.

Begitu juga dengan internet, dimana banyak siswa atau usia remaja yang pergi kewarnet (warung internet) hanya untuk chatting. Tetapi untuk mendengar ataupun melihat informasi yang berhubungan langsung dengan pengetahuan kesehatan ataupun bidang yang lainnya yang bisa dilihat melalui program televisi yang berbentuk berita, dan yang dilihat dari internet seperti pengetahuan kesehatan ataupun yang lainnya, maka cara ini lah lebih sering dilewatkan atau ditinggalkan.

Begitu juga degan membaca majalah ataupun buku. Untuk bacaan yang memberikan pengetahuan, kesehatan dan yang lainnya, maka bacaan inilah yang sering ditinggalkan, sedangkan bacaan yang berbentuk novel, cerpen, dan komik sangat digemari.

Berdasarkan uraian di atas maka jelas bahwa pengetahuan gizi siswa dapat berkontribusi terhadap pemilihan makanan siswa yang dapat mempengaruhi kondisi fisik dan motorik siswa.

\section{KESIMPULAN}

Berdasarkan analisis di atass dan oembahasan yang dikemukakan pada bagian terdahulu, maka diperlukan beberapa kesimpulan pada bagian ini tentang pengetahuan gizi siswa yang mengikuti ekstrakulikuler (olharaga) SMP N 4 Padang adalah; Pengetahuan gizi siswa yang mengikuti ekstrakulikuler (olahraga) SMP N 4 Padang mendapat skor rata-rata 73,7 \%. Dikategorikan dalam klasifikasi Sedang. Sumber pengetahuan dan pemahaman tentang gizi di dapat dari orang tua, sekolah, media dan elektronik.

Berdasarkan kesimpulan di atas, maka di kemukakan beberapa saran sebagai berikut:

1. Perlunya pemberian informasi oleh instansi terkait berupa penyuluhan kepada siswa akan pentingnya pengetahuan gizi terhadap makanan. 
2. Perlunya peningkatan pengetahuan yang lebih efektif kepada siswa dengan metode sederhana dan terarah.

3. Perlu koordinasi dan kontrol dari pihak keluarga dan sekolah dalam pemilihan makanan siswa dengan mengganti menumenu makanan, yang terdapat di kantin sekolah dan lingkungan masyarakat.

4. Perlunya penelitian labih lanjut mengenai pengetahuan gizi, guna meningkatkan kesadaran hidup masyarakat, akan pentingnya gizi dan kesehatan yang optimal.

\section{DAFTAR PUSTAKA}

Arikunto, Suharsimi. 1997. Prosedur Penelitian. Jakarta.

1990. Dasar-dasar evaluasi Pendidikan. Jakarta: Bina Aksara.

Berg, Alan. 1986. Peranan Gizi dalam Pembanguna Nasional. Jakarta: Rajawali.

Depkes RI. 1981. Tuntunan Pelaksanaan Bagi Guru. Jakarta: Depkes RI

1993. Pedoman Pengaturan Makan Atlet. Jakarta: Depkes RI.

1999. Pedoman Pengaturan Makanan. Jakarta: Dirjan Pembinaan Kesehatan Masyarakat Direktoral Bima Upaya Kesehatan Puskesmas.

Dikdesmen. 1997. Petunjuk pelaksanaan kegiatan ekstrakurikuler sebagai salah satu pembinaan jalur kesiswaan. Jakarta: Dekdikbud.

Djaeni.S,Achmad. 2004. Ilmu gizi untuik mahasiswa dan profesi. Dian Rakyat

Efendi, Dedi. 2006. Kegiatan Ekstrakurikuler Silat Tradisional Pauhdi SMP N 18 Padang. (Skripsi: UNP)

Eliza. Delvi. 1999. Penuntun kesehatan dan gizi anak TK. DIP Universitas Negri Padang

Gusril. 2004. Perkembangan motorik pada masa anak-anak. Dirjen Olahraga Departemen Pendidikan Nasional.
Hartok. Nurhayoto. 1992. Ilmu gizi zat utama. Jakarta PT. Golden Pess.

Irianto, Agus. 1988. Statistik pendidikan. Jakarta. DekDikBud.

Kuntaraf. 1999. Makanan Sehat. Bandung: Indonesia Publishing House

Lufri. 1999. Metode Penelitian. Jakarta: PT Rajawali.

Martianto, Drajat. Hardiansyah. 1992. Gizi Terapan. Depdikbud: Direktorat Jendral Pendidikan Universitas Pangan Dan Gizi Institut Pertanian Bogor.

Muchtahir, Deddi, dkk 1993. Metabolisme Zat Gizi. Jakarta: Pustaka Sinar Harapan.

Notoadmodjo, Soekidjo. 1985. Pengaturan Ilmu Perilaku Kesehatan. Jakarta: FKM-UI

1993. Pengaturan pendidikan kasehatan dan ilmu perilaku kesehatan. Yogyakarta: Andi Offset 2003. Pendidikan Dan Perilaku Kesehatan. Yogyakarta: Rineka Cipta.

$\begin{array}{lll} & \begin{array}{c}2005 . \\ \text { Perilaku Pendidikan }\end{array} & \text { Dan } \\ \text { Rineka Cehatan. Jakarta: } & \text { PT. }\end{array}$

OSIS SMAN 74 Jakarta. Ekstrakurikuler. http://OSISSMAN74JKT.Or.id/ekstrakur ikuler. Htm

Roedjito D, Djiteng. 1987. Sinopsis dan suntingan perencanaan gizi. Institut Pertanian Bogor.

Sudjana. 1991. Metode statistik. Bandung: Tarsito

.1999. Tuntunan penyusunan karya ilmiah. Bandung: Sinar Baru Algesindo.

Shah, Muhibbin. 2003. Psikologi belajar.jakarta: PT. RAJA Grafindo Persada.

Sugiyono. 2006. Metode penelitian kuantitatif, kualitatif dan $D \& R$. Bandung Alfabeta. 
Suharjo.1999. Prinsip-prinsip ilmu gizi. Bogor:

Kanisius. 